\title{
Engineering Technologies for Fluid Chemical Hydrogen Storage System
}

\author{
Bart A. van Hassel*, Randolph C. McGee, Allen Murray and Shiling Zhang \\ United Technologies Research Center, 411 Silver Lane, \\ East Hartford, Connecticut, USA
}

E-mail of the corresponding author: vanhasba@utrc.utc.com

\begin{abstract}
An efficient gas/liquid separator (GLS) was developed for separating hydrogen gas from spent liquid organic and inorganic hydrogen carriers onboard light-duty vehicles. The results show that the capacity of the GLS is sufficient for an $80 \mathrm{kWe}$ PEM fuel cell, as used in light-duty vehicle applications. A discrepancy was observed between the calculated droplet size distribution at the outlet of the GLS and the experimental results. This was explained by film formation and breakup inside the vortex finder when the GLS was operated at flow rates that exceeded its critical gas velocity.
\end{abstract}

Keywords: On-board hydrogen storage, chemical hydrogen storage, gas/liquid separation, hydrogen quality, droplet size distribution, critical gas velocity

\section{Introduction}

Automobile users have been accustomed to using liquid fuels ever since Bertha Benz filled the tank on the maiden trip of the world's first automobile at the world's first filling station (a City Pharmacy in Wiesloch, Germany), back in 1888 [1]. This event was only 18 years after the establishment of the US Weather Bureau [2], which started recording data in several Midwestern cities such as Chicago. Since then a trend has been discovered between greenhouse gas emissions by human activities (to which transportation is contributing about $29 \%$ in the US [3]) and global warming [4]. It is an enormous challenge to society to change to more sustainable forms of transportation.

The convenience of dispensing a liquid fuel with a high volumetric energy density rapidly into a compact affordable low-pressure conformal tank remains highly desirable during this transition. Liquid organic hydrogen carriers (LOHC) and liquid inorganic hydrogen carriers (LIHC) have been developed for this purpose and some examples are shown in Table 1. A common characteristic of the listed hydrogen carriers is that hydrogen gas can be released in a reactor onboard a vehicle in order to power a fuel cell or internal combustion engine.

This paper discusses the development of a gas/liquid separator system downstream of such a reactor in order to separate the hydrogen gas from the liquid spent fuel, which is important for meeting the SAE J2719 hydrogen quality guidelines [14]. This work has been performed as part of UTRC's contribution to the DOE-funded Hydrogen Storage Engineering Center of Excellence (HSECoE [15]). This center 
focuses on the design and engineering of materials-based hydrogen storage systems for light-duty vehicles that shall meet all 18 hydrogen storage targets [16] simultaneously.

Table 1, Liquid organic and inorganic hydrogen carriers

\begin{tabular}{|c|c|c|c|c|c|}
\hline & & $\begin{array}{l}\text { Material } \\
\text { gravimetric } \\
\text { capacity }\left[\mathrm{g} \mathrm{H}_{2} /\right. \\
\text { kg material] }\end{array}$ & $\begin{array}{l}\text { Material } \\
\text { volumetric } \\
\text { capacity }\left[\mathrm{g} \mathrm{H}_{2} /\right. \\
\text { Liter material] }\end{array}$ & $\begin{array}{l}\text { Regeneration } \\
\text { efficiency }\end{array}$ & Ref. \\
\hline \multirow[t]{4}{*}{ LOHC } & N-ethylcarbazole & 0.0583 & 61.8 & $>60 \%$ & [5-7] \\
\hline & Methylperhydroindole & 0.0290 & 26.1 & $?$ & [8] \\
\hline & Pentane thiol & 0.0580 & 48.7 & $?$ & {$[9,10]$} \\
\hline & CBN heterocycle & 0.0470 & 42 & $?$ & [11] \\
\hline \multirow[t]{2}{*}{ LIHC } & $\begin{array}{l}\mathrm{NH}_{3} \mathrm{BH}_{3} \text { in silicone oil } \\
\text { (50 wt.\%), } 2.35 \\
\text { equivalent }\end{array}$ & 0.0767 & 67.5 & $8-28 \%$ & $\begin{array}{l}{[12,} \\
13]\end{array}$ \\
\hline & $\begin{array}{l}\mathrm{AlH}_{3} \text { in silicone oil (50 } \\
\text { wt.\%) }\end{array}$ & 0.0504 & 60.4 & $24 \%$ & [13] \\
\hline
\end{tabular}

The $\mathrm{H}_{2}$ release by these liquid $\mathrm{H}_{2}$ carriers tends to be endothermic and a significant fraction of the stored $\mathrm{H}_{2}$ gas needs to be burned in for instance a micro-channel combustor [17]. This reduces the onboard efficiency. Ammonia Borane (AB) is a noticeable exception and releases $\mathrm{H}_{2}$ gas in an exothermic reaction. The spent fuel shall be collected at the refueling station and sent to a central processing plant for offboard regeneration of the hydrogen carrier [6,7, and 12]. Finding an energy-efficient regeneration process has been proven to be a difficult challenge, especially for the liquid inorganic hydrogen carriers [13].

\section{Experimental}

A schematic diagram of the gas/liquid separator (GLS) that was developed in close collaboration with the Eaton corporation and tested at UTRC is shown in Figure 1. The GLS comprises a demister pad, a static vane pack, a vortex containment plate and a vortex finder. It operates in a horizontal orientation in order to have a low profile onboard of a fuel cell vehicle. The two-phase mixture of hydrogen gas and spent fuel enters the GLS from the left and first passes through the demister pad on which small droplets (e.g. mist) coalesce into larger droplets that are easier to separate by the vortex that is induced by the static vane pack with a proprietary vane angle. Dry hydrogen gas is extracted from the center of the vortex by the vortex finder. Droplets spin out of the vortex against the inside surface of the GLS and form an oil film that drains under gravity into a collection tank from which it can be discharged into a spent fuel tank. The GLS was designed to have a high dynamic range due to the simultaneous use of three separation mechanisms: gravity settling, inertial impaction, and centrifugal separation. Relentless efforts on weight and volume reduction resulted 
in a total weight of $5.8 \mathrm{~kg}$ and 2.7 Liter. This improved the system gravimetric capacity from $31 \mathrm{gH}_{2} / \mathrm{kg}$ system to $41 \mathrm{gH}_{2} / \mathrm{kg}$ system and the system volumetric capacity from 36 $\mathrm{gH}_{2} / \mathrm{L}$ system to $40 \mathrm{gH}_{2} / \mathrm{L}$ system (=2017 system target) [18-20].

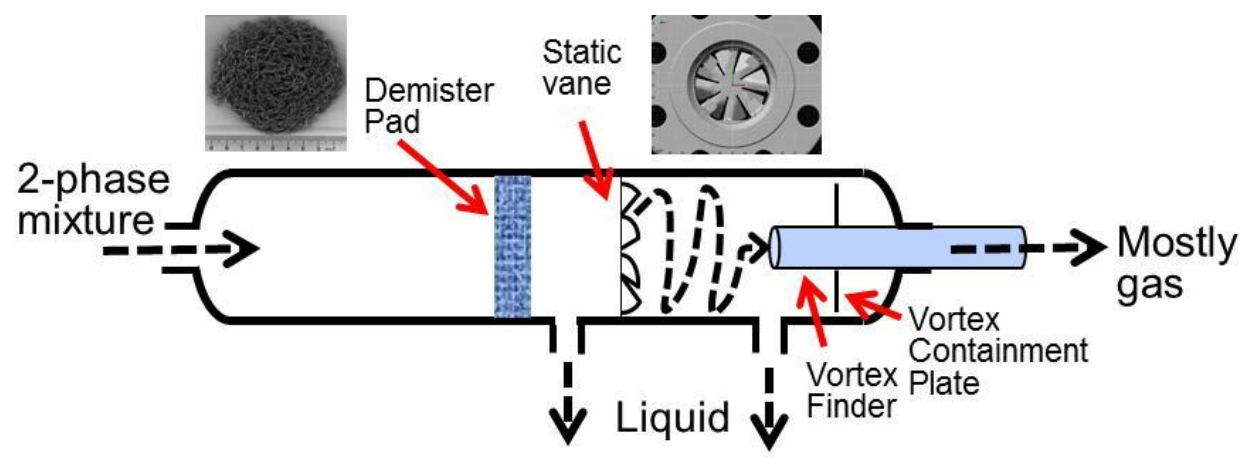

Figure 1, Schematic diagram of a GLS for separating $\mathrm{H}_{2}$ gas from the spent $\mathrm{H}_{2}$ carrier in a liquid form.

The HSECoE selected slurries of $\mathrm{AB}$ or Aluminum hydride $\left(\mathrm{AlH}_{3}\right)$ in silicone oil AR-20 as prototypical fluid forms of an exothermic and endothermic chemical hydrogen storage material that would enable a hydrogen storage system capable of meeting all of the 18 DOE targets for light-duty vehicles simultaneously [18]. It was decided to evaluate the performance of the GLS as close as possible to the required operating conditions for this slurry-based chemical hydrogen storage system. However the $A B$ and Alane slurries were only available in very limited quantities, which would have been insufficient for testing the GLS. Therefore the GLS was characterized with a two-phase silicone oil AR-20 / $\mathrm{N}_{2}$ gas mixture but at the flow rates required for an actual GLS (liquid: 0.2-0.7 L/min, gas: $300-900$ slpm).

The experimental setup for testing the GLS performance was documented in ref. 21. It incorporated a gas-cooler (Exergy, tube-in-tube heat exchanger, at $20^{\circ} \mathrm{C}$ ) downstream of the GLS. The liquid carry-over amount (CO) is defined as the weight of the silicone oil that was collected in a coalescence filter (Parker Hannifin Corporation) downstream of this gas-cooler and this is the sum of any droplets that passed through the vortex finder and any vapor that would have condensed on the heat exchanger surface and drained by gravity. The separation efficiency (SE) of the GLS is defined as:

$S E($ in $\%)=100 *\left(1-\frac{C O}{F}\right)$

where $\mathrm{CO}=$ liquid carry-over amount collected at gas outlet [g] and F=silicone oil amount fed into GLS [g]. The SE is hence defined as the carry-over amount relative to the silicone oil amount that was supplied to the GLS. A Malvern Mastersizer was used to measure the droplet size distribution at the outlet of the GLS in order to diagnose the performance of the GLS and to validate the Computational Fluid Dynamics (CFD) model.

The chemical hydrogen storage system with $A B$ in silicone oil $A R-20$ as the $\mathrm{H}_{2}$ storage material relied on the hot recirculation of spent fuel in order to improve the onboard 
energy efficiency [18]. Experiments at elevated temperature $\left(170^{\circ} \mathrm{C}\right)$ showed a significant carry-over of silicone oil vapor, which was undesired. This was due to the high vapor pressure of silicone oil AR-20, to be discussed in section 4.3. The operating temperature of the GLS was reduced to a maximum temperature of $70^{\circ} \mathrm{C}$ in order to reduce silicone oil vapor carry-over. Silicone oils with a significant lower vapor pressure were identified but not tested experimentally.

\section{Model development}

A Simulink framework was developed for comparing different $\mathrm{H}_{2}$ storage systems on a common basis, as reported in ref. 22 and 23. UTRC used the gas and liquid flow rates from those simulations in order to determine that the flow regime at the inlet of the GLS would be in the annular-dispersed or stratified wavy flow regime according to the Taitel and Dukler generalized flow regime map for horizontal two-phase flow [24]. It was not feasible to measure the silicone oil droplet size distribution due to the relative high silicone oil concentration at the inlet of the GLS. Therefore the Harwell procedure was followed in order to estimate the inlet droplet size distribution [25]. In this procedure, the 'Sauter mean' of the drop diameter can be estimated from the following correlation [26]:

$\langle x\rangle_{S a}=1.91 D_{t} \frac{R e^{0.1}}{W e^{0.6}}\left(\frac{\rho_{g}}{\rho_{l}}\right)^{0.6}+D_{t} \frac{m_{l}}{\rho_{l} \mu_{l}}$

where Re and We are the Reynolds and Weber number, respectively. They are defined as,

$\boldsymbol{R} e=\frac{\rho_{g} v_{t} D_{t}}{\mu_{g}}$

$W e=\frac{\rho_{g} v_{t}^{2} D_{t}}{\sigma}$

and where $<x>s_{\mathrm{sa}}$ is the Sauter mean drop diameter, $\mathrm{D}_{\mathrm{t}}$ is the internal diameter of the pipe, $\rho_{g}$ and $\rho_{l}$ are the gas and liquid densities, $\mu_{g}$ is the gas viscosity, $v_{t}$ is the mean gas velocity within the pipe and $\sigma$ is the interfacial surface tension, $m_{l}$ is the silicone oil mass flux through the inlet tube cross sectional area $\left[\mathrm{kg} / \mathrm{m}^{2} / \mathrm{s}\right] ; \mu_{1}$ is the silicone oil viscosity [Pa.s].

The Sauter mean droplet diameter was converted to a volume-average drop diameter through the following approximation:

$d_{50}=\exp \left(\sigma^{2} / 2\right) *\langle x\rangle_{S a}$

which is based on a log-normal drop size distribution [27]. The probability density function of the lognormal distribution is defined as,

$d v=\frac{1}{\sigma \sqrt{2 \pi}} \exp \left[-\frac{1}{2}\left(\frac{\ln d_{p}-\ln d_{v 50}}{\sigma}\right)^{2}\right] \frac{d d_{p}}{d_{p}}$ 
and where $d v$ is the fraction of the liquid volume contained in drops with diameters between $\mathrm{dp}$ and $\mathrm{dp}+\mathrm{ddp}$ and $\sigma$ is the standard deviation. A characteristic width $\sigma=0.81$ was used in this study, which was reported by Al-Sarkhi and Hanratty [27]. Silicone oil with a surface tension of $9.65 \times 10^{-3} \mathrm{~N} / \mathrm{m}$ and a dynamic viscosity of $20 \mathrm{mPa}$.s was used as the agent for turning $A B$ into a slurry. Examples of the estimated droplet size distributions at the inlet of the GLS are shown in Figure 2a.

Ansys Fluent was employed to simulate the gas and liquid separation process in the GLS. The geometric features of the GLS were captured in a 22.5 degrees sector with periodic boundary conditions in order to reduce computational time. The total grid size was 0.22 million cells. A steady state, pressure-based solver of the Reynolds-averaged Navier-Stokes equations (or RANS equations) was used. A realizable k- $\varepsilon$ turbulence model with standard wall functions was chosen to represent turbulence. Gas phase and discrete phase were both employed to represent gas and liquid droplet flow and their interaction (one way interaction from droplet to gas only). A mass flow inlet boundary condition was chosen, which includes both gas and droplets (size distribution). A pressure boundary condition was used at the outlet. The carryover silicone oil flow rate and the droplet size distribution were recorded. In later stages of the study, a separate CFD model was developed for oil film formation and breakup inside the vortex finder. It used an Eulerian wall film model with the initial wall film thickness set to zero.

Table 2, GLS operating conditions for CFD modeling $\left(70^{\circ} \mathrm{C}, 12\right.$ bar $)$

\begin{tabular}{|c|c|c|}
\hline CFD run & $\begin{array}{c}\text { Silicone oil } \\
\text { AR 20 flow } \\
\text { rate [lpm] }\end{array}$ & $\begin{array}{c}\text { N2 gas flow } \\
\text { rate [sipm] }\end{array}$ \\
\hline 301 & 0.72 & 900 \\
\hline 302 & 0.72 & 700 \\
\hline 303 & 0.72 & 600 \\
\hline 304 & 0.72 & 300 \\
\hline 311 & 0.20 & 900 \\
\hline 313 & 0.20 & 600 \\
\hline 314 & 0.20 & 300 \\
\hline
\end{tabular}


a)

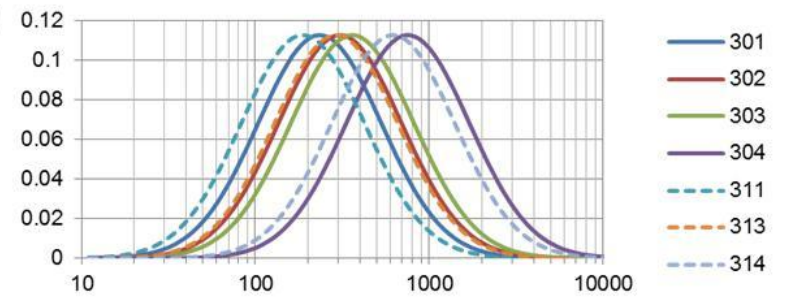

b)
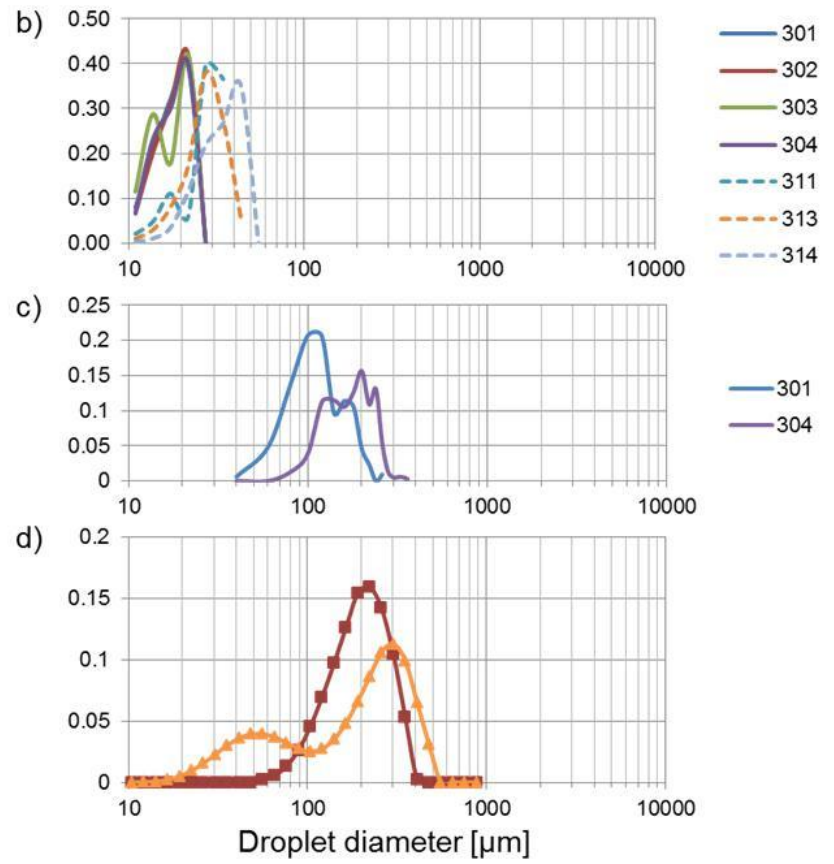

Figure 2, Droplet size distributions at $70^{\circ} \mathrm{C}, 12$ bar and various $\mathrm{N}_{2}$ and silicone AR-20 flow rates (Table 2): a) Inlet of the GLS b) Outlet of the GLS (no filming), c) Outlet of the GLS with filming inside the vortex finder, d) Two representative but distinctly different experimental droplet size distributions at a $\mathrm{N}_{2}$ gas flow rate of $600 \mathrm{slpm}$ and a silicone oil AR-20 flow rate of $0.365 \mathrm{lpm}$.

\section{Results and discussion}

\subsection{GLS performance}

Figure 3 shows the separation efficiency at $70^{\circ} \mathrm{C}$ as a function of the $\mathrm{N}_{2}$ gas flow at two different oil flow rates ( 0.2 and $0.72 \mathrm{lpm}$ ) and two different pressures (12 and $16 \mathrm{bar}$ ). There is a critical $\mathrm{N}_{2}$ gas flow rate below which the liquid carryover becomes very low (approaching $100 \%$ separation efficiency). This critical $\mathrm{N}_{2}$ gas velocity can be used in the Souders-Brown equation in order to estimate that the critical $\mathrm{H}_{2}$ gas flow rate would be a factor 3.75 higher than for $\mathrm{N}_{2}$ gas. This means that this GLS will be able to separate $\mathrm{H}_{2}$ from silicone oil up to an electrical power level of about $80 \mathrm{kWe}$ by the PEM fuel cell. In other words, the GLS that was developed and tested has a capacity that is sufficient for this light-duty vehicle application. 
a)

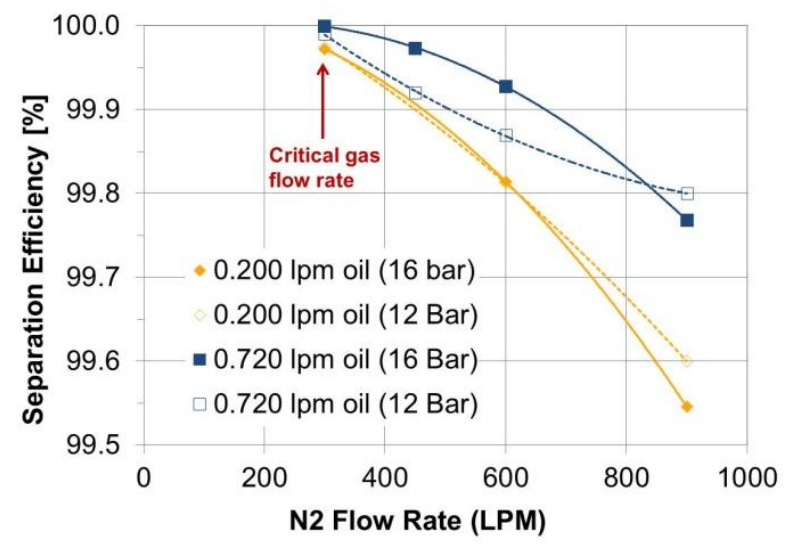

b)

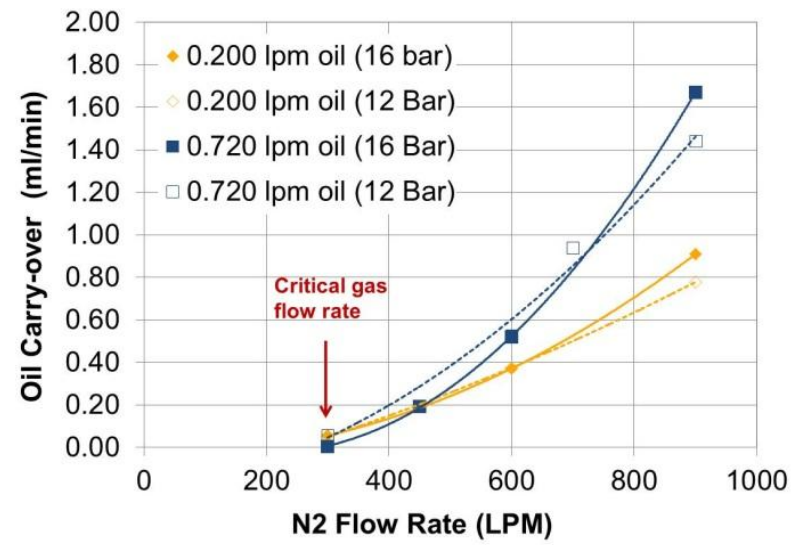

Figure 3, GLS performance: a) Separation Efficiency (SE), b) Liquid carry-over flow rate.

\subsection{Model validation}

Figure 4 shows a result from the CFD model of the GLS. The two-phase gas/liquid mixture enters from the top left and first passes through the demister pad before the static vane pack induces a vortex. The large droplets spin out of the vortex and form an silicone oil film on the inside surface of the GLS, which drains under gravity and gets collected in a holding tank (not shown). Dry gas is extracted from the center of the vortex by the vortex finder.

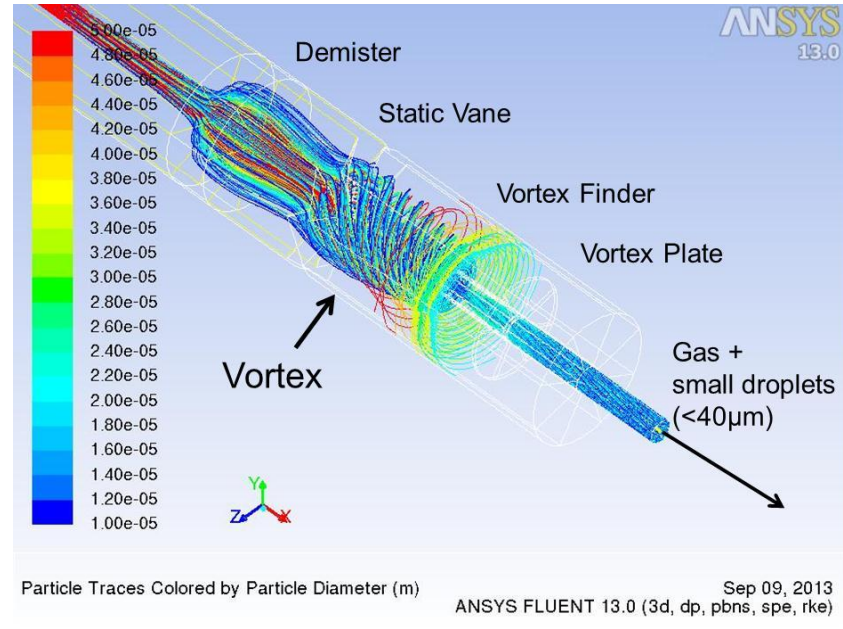

Figure 4, CFD model results $\left(70^{\circ} \mathrm{C}, 12\right.$ bar, 900 slpm, 0.2 lpm). Droplet traces inside the GLS have been colored by their droplet diameter.

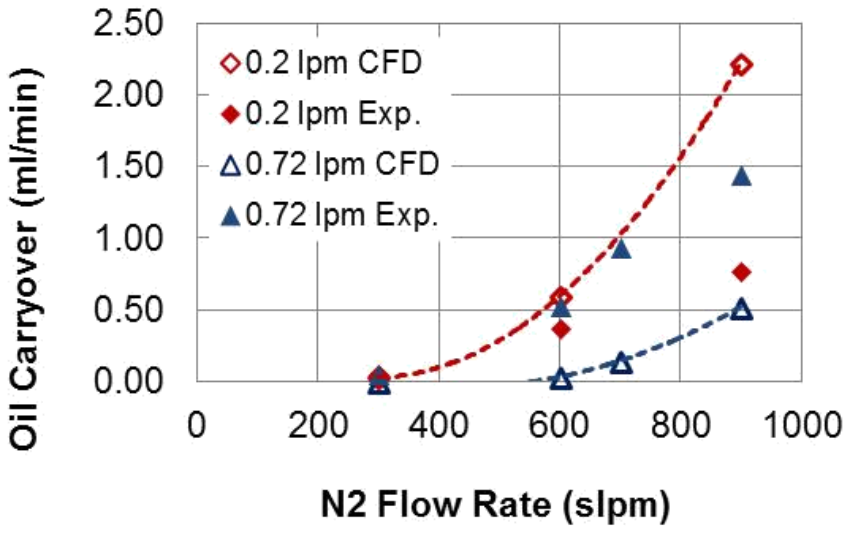

Figure 5, Comparison between the oil carryover as predicted by the CFD model (open symbols and dashed lines) and as measured experimentally $\left(70^{\circ} \mathrm{C}, 12 \mathrm{bar}\right.$, closed symbols). 
Figure 5 shows a comparison between the calculated silicone oil carryover flow rate and the experimental results at $70^{\circ} \mathrm{C}$ and 12 bar. The calculated critical $N_{2}$ gas flow rate coincided with the experimental value. However, the model is overpredicting the carryover flow rate at a low oil flow rate (e.g. $0.2 \mathrm{lpm}$ ) and underpredicting that carryover flow rate a higher oil flow rates (e.g. 0.72 lpm).

Figure 2 shows a compilation of the droplet size distributions at the inlet of the GLS, the predicted droplet size distribution at the outlet of the GLS and the measured droplet size distribution at the outlet of the GLS. The measured droplet size distribution (Figure 2d) is significant larger than predicted (Figure 2b). Separate CFD calculations with an Eulerian wall film model indicate that oil droplets form an oil film on the inside surface of the vortex finder. This oil film breaks up as a result of the high $\mathrm{N}_{2}$ flow rate into droplets with a size of 100 to $300 \mu \mathrm{m}$ (Figure 2c), which is a similar range as was measured with the Malvern Mastersizer. This model of the GLS can be used to scale it to different capacity requirements but still some testing will be required in order to verify the value of the critical gas flow rate.

\subsection{Volatility}

A significant increase in the liquid carryover flow rate was observed when the GLS was operated at more elevated temperatures (e.g. $\left.170^{\circ} \mathrm{C}\right)$. Subsequently, the boiling point temperature range was determined by chromatographically simulated distillation (ASTM D2887-13 [28]). The boiling temperature range of the silicone oil AR-20 was from $200^{\circ} \mathrm{C}$ to $500^{\circ} \mathrm{C}$. The vapor pressure of the silicone oil AR-20 was determined as a function of temperature by means of an isoteniscope (ASTM D2879-10 [29]). A vapor pressure was recorded of about 0.1 bar at $170^{\circ} \mathrm{C}$. Dow Chemical identified many different siloxane species (e.g. $\mathrm{Me}_{3} \mathrm{SiOH}$ and $\mathrm{Me}_{3} \mathrm{SiOSiMe}_{2} \mathrm{OH}$ ) in the vapor phase above the silicone oil. This is not acceptable for PEM fuel cells and additional gas cleanup (e.g. adsorption) will therefore be required, which will add weight and volume to the chemical hydrogen storage system. UTRC identified several other silicone oils (DOW Corning 702, 704 and 705 diffusion pump oils) with orders of magnitude lower vapor pressure while still having a reasonable low viscosity. Those are worth investigating as a replacement for AR-20. The $\mathrm{H}_{2}$ gas could also be cooled in order to condense volatile impurities. This may still need to be followed by a polishing step.

\section{Conclusions}

A compact GLS $(5.8 \mathrm{~kg}, 2.7 \mathrm{~L})$ was developed for separating $\mathrm{H}_{2}$ gas from spent chemical hydrogen storage materials in a liquid form. The GLS has high separation efficiency up to a critical gas flow rate, beyond which liquid starts to carry over into a coalescence filter. The GLS capacity at the critical flow rate is sufficient to support an 80 kWe PEM fuel cell of a light-duty vehicle. Residual gas cleanup will be needed when the chemical hydrogen storage material or the fluid used to form a slurry with the chemical hydrogen storage material would have a high volatility at the temperature at which the GLS is operated. It will be important to select materials with a low volatility in order to avoid the weight and volume penalty associated with such a gas cleanup system. 


\section{Acknowledgement}

This paper was prepared as an account of work supported by EERE (Energy Efficiency and Renewable Energy) and the FCTO (Fuel Cell Technologies Office) of the U.S. Department of Energy under Contract No. DE-FC36-09G019006. Neither the United States Government nor any agency thereof, nor any of their employees, makes any warranty, express or implied, or assumes any legal liability or responsibility for the accuracy, completeness, or usefulness of any information, apparatus, product, or process disclosed, or represents that its use would not infringe privately owned rights. Reference herein to any specific commercial product, process, or service by trade name, trademark, manufacturer, or otherwise does not necessarily constitute or imply its endorsement, recommendation, or favoring by the United States Government or any agency thereof. The views and opinions of authors expressed herein do not necessarily state or reflect those of the United States Government or any agency thereof.

The authors would like to thank all members of the HSECoE for stimulating discussions and Ned Stetson, Jesse Adams and Bob Bowman for their outstanding support. The authors also would like to thank Anthony Y. Chiang from the Eaton corporation.

\section{References}

[1] Elis, Angela: Mein Traum ist länger als die Nacht, Wie Bertha Benz ihren Mann zu Weltruhm fuhr, Hamburg, Germany : Hoffmann und Campe Verl., 2010. ISBN 978-3455-50146-9

[2] Hughes, Patrick, A century of weather service: a history of the birth and growth of the national weather service, 1870-1970, Gordon and Breach, 1970

[3] U.S. Environmental Protection Agency, Inventory of Greenhouse Gas Emissions and Sinks: 1990-2007, April 2009.

[4] IPCC, 2013: Climate Change 2013: The Physical Science Basis. Contribution of Working Group I to the Fifth Assessment Report of the Intergovernmental, Panel on Climate Change [Stocker, T.F., D. Qin, G.-K. Plattner, M. Tignor, S.K. Allen, J. Boschung, A. Nauels, Y. Xia, V. Bex and P.M. Midgley (eds.)]. Cambridge University Press, Cambridge, United Kingdom and New York, NY, USA, 1535 pp.

[5] R.K. Ahluwalia, T.Q. Hua, J-K Peng, M. Kromer, S. Lasher, K. McKenney, K. Law and J. Sinha, Technical assessment of organic liquid carrier hydrogen storage systems for automotive applications, June 21, 2011.

[6] D. Teichmann, W. Arlt and P. Wasserscheid, Liquid Organic Hydrogen Carriers as an efficient vector for the transport and storage of renewable energy, International Journal of Hydrogen Energy 37 (2012), pp. 18118-18132. 
[7] J. von Wild, T. Friedrich, A. Cooper, B. Toseland, G. Muraro, W. TeGrotenhuis, Y. Wang, P. Humble and A. Karim, Liquid Organic Hydrogen Carriers (LOHC): An auspicious alternative to conventional hydrogen storage technologies, $18^{\text {th }}$ World Hydrogen Energy Conference 2010 - WHEC 2010, Proceedings of the WHEC, May 1621, 2010, Essen.

[8] C.M. Jensen, D. Brayton and S. Jorgensen, Development of a practical hydrogen storage system based on liquid organic hydrogen carriers and a homogeneous catalyst, US DOE Annual Merit Review Meeting, May 15, 2012.

[9] WO 2011/053326, Dehydrogenation of cyclic thioethers, May 5, 2011

[10] E.D. Naeemi, D. Graham and B.F. Norton, Introducing HYDRNOL ${ }^{\mathrm{TM}}$ : Organic Liquid Storge for Hydrogen, Material Matters, Sigma-Aldrich, Volume 2, Article 2, $11 / 29 / 2011$.

[11] Liu, S-Y, Novel Carbon(C)-Boron(B)-Nitrogen(N)-Containing $\mathrm{H}_{2}$ storage materials, US DOE Annual Merit Review Meeting, May 15, 2013.

[12] T.Q. Hua and R.K. Ahluwalia, Off-board regeneration of ammonia borane for use as a hydrogen carrier for automotive fuel cells, International Journal of Hydrogen Energy, 37 (2012), pp. 14382-14392.

[13] B.D. James, W.G. Colella and M. Paster, Alane and ammonia-borane off-board recycle analysis, U.S. DOE Fuel Pathways Integration Technical Team Roadmap (FPITT) Meeting, October 23 and 24, 2012.

[14] Information Report on the Development of a Hydrogen Quality Guideline for Fuel Cell Vehicles, SAE International Surface Vehicle Information Report, J2719 APR2008, Revised 2008-04

[15] http://www.hsecoe.org/

[16] http://energy.gov/sites/prod/files/2014/03/f12/targets onboard hydro storage.pdf

[17] Mohammad Ghazvini and Vinod Narayanan, Design of a Microscale CombustorHeat Exchanger for Low Temperature Applications, ASME 2013 Heat Transfer Summer Conference, Volume 2: Heat Transfer Enhancement for Practical Applications; Heat and Mass Transfer in Fire and Combustion; Heat Transfer in Multiphase Systems; Heat and Mass Transfer in Biotechnology, Minneapolis, Minnesota, USA, July 14-19, 2013

[18] Kriston P. Brooks, Troy A. Semelsberger, Kevin L. Simmons and Bart A. van Hassel, Slurry-based chemical hydrogen storage systems for automotive fuel cell applications, Journal of Power Sources, 2014, Volume 268, Pages 950-959. 
[19] J. Holladay, K. Brooks, K. Simmons, E. Ronnebrö, M. Weimar, A. Karkamkar, R. Pires and M. Westman, Systems engineering of chemical hydrogen, pressure vessel, and balance of plant for on-board hydrogen storage, US DOE Annual Merit Review Meeting, May 14, 2013.

[20] T.A. Semelsberger, B.L. Davis, B.D. Rekken, B. Pajik, and J.I. Tafoya, Chemical hydrogen rate modeling, validation, and system demonstration, US DOE Annual Merit Review Meeting, May 14, 2013.

[21] B.A. van Hassel, J.M. Pasini, R.C. McGee, L. Chiappetta, A. Murray, J.C. Rampone, J.R. Karra, D. Gerlach, I. Fedchenia, J. Khalil and R. Brown, Advancement of systems designs and key engineering technologies for materials based hydrogen storage, US DOE Annual Merit Review Meeting, May 14, 2013.

[22] José Miguel Pasini, Bart A. van Hassel, Daniel A. Mosher and Michael J. Veenstra, "System modeling methodology and analyses for materials-based hydrogen storage," Int. J. Hydrogen Energy 37, 2874-2884 (2012)

[23] Matthew Thornton, Jon Cosgrove, Aaron Brooker, José Miguel Pasini, and Michael J. Veenstra, "Development of a vehicle level simulation model for evaluating the trade-off between various advanced on-board hydrogen storage technologies for fuel cell vehicles," SAE Technical Paper 2012-01-1227, SAE 2012 World Congress \& Exhibition, April 2012, Detroit, MI, USA (2012).

[24] Y. Taitel and A.E. Dukler, A Model for Predicting Flow Regime Transitions in Horizontal and Near Horizontal Gas-Liquid Flow, AIChE Journal, 22 (1976),1, pp. 47-55.

[25] A.C. Hoffman and L.E. Stein, Gas Cyclones and Swirl Tubes: Principles, Design and Operation, Springer, New York, Berlin (2008).

[26] B.J. Azzopardi, Drops in Annular Two-Phase Flow, Int. J. Multiphase Flow, Vol. 23, 1997, Suppl., pp. 1-53.

[27] A. Al-Sarkhi and T.J. Hanratty, Effect of pipe diameter on the drop size in a horizontal annular gas-liquid flow, International Journal of Multiphase Flow 28 (2002) 1616-1629

[28] ASTM D2887 - 13 Standard Test Method for Boiling Range Distribution of Petroleum Fractions by Gas Chromatography

[29] ASTM D2879 - 10 Standard Test Method for Vapor Pressure-Temperature Relationship and Initial Decomposition Temperature of Liquids by Isoteniscope 